\title{
Prefrontal Cortical Circuit for Depression- and Anxiety- Related Behaviors Mediated by Cholecystokinin: Role of $\Delta$ FosB
}

\author{
Vincent Vialou, ${ }^{1,6,7,8}$ Rosemary C. Bagot, ${ }^{1}$ Michael E. Cahill, ${ }^{1}$ Deveroux Ferguson, ${ }^{1}$ Alfred J. Robison, ${ }^{2}$ David M. Dietz, ${ }^{3}$ \\ Barbara Fallon, ${ }^{2}$ Michelle Mazei-Robison, ${ }^{2}$ Stacy M. Ku, ${ }^{1}$ Eileen Harrigan, ${ }^{1}$ Catherine A. Winstanley, ${ }^{4}$ Tej Joshi, ${ }^{1}$ \\ Jian Feng, ${ }^{1}$ Olivier Berton, ${ }^{5}$ and Eric J. Nestler ${ }^{1}$ \\ ${ }^{1}$ Fishberg Department of Neuroscience and Friedman Brain Institute, Icahn School of Medicine at Mount Sinai, New York, New York 10029, ${ }^{2}$ Department of \\ Physiology, Michigan State University, Lansing, Michigan 48824, ${ }^{3}$ Department of Pharmacology and Toxicology, University of Buffalo, Buffalo, New York \\ 14214, ${ }^{4}$ Department of Psychology, University of British Columbia, Vancouver, British Columbia, Canada, ${ }^{5}$ Department of Psychiatry, University of \\ Pennsylvania Medical School, Philadelphia, Pennsylvania 19104, and ${ }^{6}$ Institut National de la Santé et de la Recherche Médicale, U1130, ${ }^{7}$ Centre National de \\ la Recherche Scientifique, Unité Mixte de Recherche 8246, and ${ }^{8}$ Université Pierre et Marie Curie, UM CR18, Sorbonne Université, Paris, France
}

Decreased medial prefrontal cortex (mPFC) neuronal activity is associated with social defeat-induced depression- and anxiety-like behaviors in mice. However, the molecular mechanisms underlying the decreased mPFC activity and its prodepressant role remain unknown. We show here that induction of the transcription factor $\triangle$ FosB in mPFC, specifically in the prelimbic (PrL) area, mediates susceptibility to stress. $\Delta$ FosB induction in PrL occurred selectively in susceptible mice after chronic social defeat stress, and overexpression of $\Delta$ FosB in this region, but not in the nearby infralimbic (IL) area, enhanced stress susceptibility. $\Delta$ FosB produced these effects partly through induction of the cholecystokinin (CCK)-B receptor: CCKB blockade in mPFC induces a resilient phenotype, whereas CCK administration into mPFC mimics the anxiogenic- and depressant-like effects of social stress. We previously found that optogenetic stimulation of mPFC neurons in susceptible mice reverses several behavioral abnormalities seen after chronic social defeat stress. Therefore, we hypothesized that optogenetic stimulation of cortical projections would rescue the pathological effects of CCK in mPFC. After CCK infusion in MPFC, we optogenetically stimulated mPFC projections to basolateral amygdala or nucleus accumbens, two subcortical structures involved in mood regulation. Stimulation of corticoamygdala projections blocked the anxiogenic effect of CCK, although no effect was observed on other symptoms of social defeat. Conversely, stimulation of corticoaccumbens projections reversed CCK-induced social avoidance and sucrose preference deficits but not anxiogenic-like effects. Together, these results indicate that social stress-induced behavioral deficits are mediated partly by molecular adaptations in mPFC involving $\triangle$ FosB and CCK through cortical projections to distinct subcortical targets.

Key words: accumbens; amygdala; anxiety; CCK; depression; mPFC

\section{Introduction}

Several anatomically and functionally interconnected limbic brain regions, including medial prefrontal cortex (mPFC), hippocampus, amygdala, and nucleus accumbens (NAc), are implicated in mediating key symptoms of depression and anxiety (Bremner, 1999; Dre-

Received April 29, 2013; revised Jan. 30, 2014; accepted Feb. 3, 2014.

Author contributions: V.V., R.C.B., J.F., and E.J.N. designed research; V.V., R.C.B., M.E.C., D.F., A.J.R., S.M.K. D.M.D., B.F., M.M.-R., E.H., T.J., J.F., and O.B. performed research; C.A.W. and O.B. contributed unpublished reagents/analytic tools; V.V., R.C.B., M.E.C., D.F., A.J.R., S.M.K., D.M.D., B.F., M.M.-R., E.H., C.A.W., T.J., J.F., and 0.B. analyzed data; V.V., R.C.B., and E.J.N. wrote the paper.

This work was supported by the National Institute of Mental Health (E.J.N.) and the Brain \& Behavior Research Foundation National Alliance for Research on Schizophrenia and Depression Young Investigator Award to V.V.

The authors declare no competing financial interests.

Correspondence should be addressed to Dr. Eric J. Nestler, Fishberg Department of Neuroscience and Friedman Brain Institute, Icahn School of Medicine at Mount Sinai, One Gustave L. Levy Place, Box 1065, New York, NY 10029-6574. E-mail: eric.nestler@mssm.edu.

DOI:10.1523/JNEUROSCI.1787-13.2014

Copyright $\odot 2014$ the authors $\quad 0270-6474 / 14 / 343878-10 \$ 15.00 / 0$ vets, 2001; Keedwell et al., 2005; Mayberg et al., 2005; Bremner, 2006, 2007; Krishnan and Nestler, 2008; Feder et al., 2009). For example, the absence of cortical feedback to amygdala is correlated with dysphoric emotions and reverts to normal levels upon successful treatment. The antidepressant effects of deep brain stimulation of subgenual cingulate cortex, an area of $\mathrm{mPFC}$, are associated with restoration of both cortical and subcortical brain activity to normal levels (Mayberg et al., 2005; Nahas et al., 2010). Similarly, deep brain stimulation of NAc is antidepressant and anxiolytic and correlates with altered metabolism in NAc, amygdala, and MPFC (Schlaepfer et al., 2008; Bewernick et al., 2010; Grubert et al., 2011). These data support a neural network hypothesis of mood disorders in which antidepressant treatments, regardless of mechanisms, normalize activity in both underactive cortical and overactive subcortical circuits (Kennedy et al., 2001; Mayberg et al., 2005; Kennedy and Giacobbe, 2007; Fales et al., 2008; Fales et al., 2009; Leistedt and Linkowski, 2013). 
Animal models involving chronic exposure to physical or psychological stress impair the structure and function of neurons in mPFC (Radley et al., 2006), amygdala (Akirav and Maroun, 2007), hippocampus (Surget et al., 2011), and NAc (Vialou et al., 2010; Christoffel et al., 2011). Chronic social defeat stress, an ethologically valid model of depression (Berton et al., 2006), decreases $\mathrm{mPFC}$ neuronal activity as inferred from reduced expression of Zif268 and c-Fos (Covington et al., 2005; Covington et al., 2010). Furthermore, optogenetic stimulation of mPFC reverses these deficits and exerts antidepressant-like effects (Covington et al., 2010), confirming the importance of mPFC in mood-related phenomena. The rodent $\mathrm{mPFC}$, as in primates, controls emotional behavior in part through projections to basolateral amygdala (BLA) and NAc (Vogt et al., 1992; Barbas and Blatt, 1995; Heidbreder and Groenewegen, 2003). Nevertheless, the molecular mechanisms that mediate this role of $\mathrm{mPFC}$ remain unknown.

The present study focused initially on $\Delta$ FosB, a stable transcription factor that is induced in NAc by chronic social defeat stress where it opposes stress susceptibility (Vialou et al., 2010). We performed brain-wide mapping of $\Delta$ FosB induction after defeat stress and found, similar to earlier studies (Perrotti et al., 2004; Nikulina et al., 2008; Lehmann and Herkenham, 2011), robust induction in mPFC. Surprisingly, we found that such $\triangle$ FosB induction in mPFC promotes stress susceptibility. We identified the cholecystokinin (CCK)-B receptor as a molecular target of $\triangle \mathrm{FosB}$ in $\mathrm{mPFC}$, where CCKergic neurotransmission has been implicated in both anxiogenic and depressogenic effects of social stress (Becker et al., 2001, 2008). We found that CCK activity in mPFC is both necessary and sufficient for the anxietyand depression-like effects of social stress. Moreover, by use of optogenetic approaches, we demonstrate specific actions of CCK in $\mathrm{mPFC}$ subcircuits: CCK in $\mathrm{MPFC}-\mathrm{BLA}$ projections mediates anxiety symptoms, whereas CCK in mPFC-NAc projections mediates depression symptoms.

\section{Materials and Methods}

Experiment 1: brain-wide mapping of $\Delta$ FosB induction by chronic social defeat stress. Eight-week-old C57BL/6J male mice were subjected to chronic social defeat stress for 10 consecutive days as described previously (Berton et al., 2006; Krishnan et al., 2007; Vialou et al., 2010) (see Table 1; Fig. 1A). Briefly, each mouse was exposed to an unfamiliar, aggressive male CD1 retired breeder mouse for $5 \mathrm{~min}$ per day. After direct interaction with the $\mathrm{CD} 1$ aggressor $(5 \mathrm{~min})$, animals were placed in an adjacent compartment of the same cage for the next $24 \mathrm{~h}$ with sensory, but not physical, contact. Control animals were housed in equivalent cages but with members of the same strain. Social interaction tests were performed $24 \mathrm{~h}$ after the final day of defeat. Social avoidance to an unfamiliar CD1 male mouse was assessed according to published protocols. The time spent in the "interaction zone" (an 8-cm-wide corridor surrounding the cage) was measured. Segregation of defeated mice into susceptible and resilient subpopulations was performed as described previously (Krishnan et al., 2007; Vialou et al., 2010). Because the majority of control mice spend more time interacting with a social target than with an empty target enclosure, an interaction ratio of 100 (equal time spent in the interaction zone in the presence vs absence of a social target) is used as a cutoff: mice with scores $<100$ are labeled as "susceptible," and those with scores $\geq 100$ as "resilient." Extensive behavioral, biochemical, and electrophysiological analyses support the validity of these distinct susceptible and resilient subpopulations (Krishnan et al., 2007; Wilkinson et al., 2009; Vialou et al., 2010).

Right after the social interaction test, mice were anesthetized and perfused intracardially with $4 \%$ paraformaldehyde/PBS. Cell counts for $\Delta \mathrm{FosB}^{+}$neurons in NAc were performed as described previously (Vialou et al., 2010). Brains were cryoprotected with $30 \%$ sucrose and coronal sections $(30 \mu \mathrm{m})$ were cut on a freezing microtome and processed for immunohistochemistry. Free-floating sections were preincubated in a blocking buffer containing $0.3 \%$ Triton and 3\% normal goat serum. $\Delta$ FosB was detected using rabbit polyclonal antibodies raised against the $\mathrm{N}$-terminal portion of the protein (1/1000 Santa Cruz Biotechnology, catalog \#sc-48) in the same buffer, then processed with biotinylated goat anti-rabbit IgG antibodies and avidin-biotin peroxidase complex method with DAB as a substrate (Vector Laboratories). Diaminobenzidine incubation times were kept constant for all conditions (100 s). Slices were mounted, dehydrated, and coverslipped. $\Delta$ FosB-immunopositive cells showed a specific brown staining in the nucleus and were quantified by an observer blind to the treatment conditions using a microscope (20× magnification). Three selected brain sections spanning each brain area were chosen per mouse for quantification. Anatomical segregation of each brain region was performed by comparing the section with the Paxinos mouse brain atlas. Conditions for immunohistochemistry were optimized to reduce background levels to the minimum allowing the correct identification of $\Delta$ FosB-positive cells. Mean values were calculated for each animal and considered as an individual observation for statistical analysis. Although the antibody used recognizes both $\Delta$ FosB and full-length FosB, we know by Western blotting that only $\Delta \mathrm{FosB}$ is detectable under the conditions studied (Perrotti et al., 2004; Vialou et al., 2010).

Experiment 2: identification of social stress-induced $\Delta$ FosB neuronal phenotype in $m P F C$. To examine expression of $\triangle \mathrm{FosB}$ in cortical GABAergic neurons, we used tissues from GAD2-tdTomato mice exposed to chronic social defeat stress and stained for $\Delta$ FosB as described above (see Fig. $1 B$ ). Mice were generated by breeding knockin GAD2-Cre mice (Gad2tm2(cre)Zjh/J; JAX stock number 010802) (Taniguchi et al., 2011) with (B6.Cg-Gt(ROSA)26Sortm9(CAG-tdTomato)Hze/J; JAX stock number 007908) that carry floxed-stop controlled tdTomato (RFP variant).

Experiment 3: behavioral effects of $\Delta$ FosB overexpression in the prelimbic $(\operatorname{PrL})$ and infralimbic (IL) cortex. Stereotaxic surgery was performed on adult male mice ( 8 weeks) to inject HSV- $\Delta$ FosB-GFP or HSV-GFP into the PrL or IL regions of mPFC. Briefly, mice were anesthetized using a mixture of ketamine $(10 \mathrm{mg} / \mathrm{kg})$ and xylazine $(1 \mathrm{mg} / \mathrm{kg})$, and the following stereotaxic coordinates were used for viral delivery for PrL: $1.8 \mathrm{~mm}$ (anterior/posterior), $0.65 \mathrm{~mm}$ (lateral), $-2.2 \mathrm{~mm}$ (dorsal/ventral); and for IL: $1.9 \mathrm{~mm}$ (anterior/posterior), $0.75 \mathrm{~mm}$ (lateral), $-2.8 \mathrm{~mm}$ (dorsal/ ventral) at an angle of $10^{\circ}$ from the midline (relative to bregma). A total of $0.5 \mu$ l of purified virus was delivered bilaterally over a 5 min period $(0.1 \mu \mathrm{l} / \mathrm{min})$ followed by $5 \mathrm{~min}$ of rest. Viral injection sites were confirmed using standard histological methods (see Fig. $1 C$ ). Although it is not possible to selectively target PrL versus IL in mice with perfect accuracy, the data in Figure $1 C$ illustrate that it is very feasible to predominantly target one region or the other. Indeed, the distinct behavioral effects obtained from targeting the two regions (see Results) substantiate this approach. The first batch of mice was used exclusively in a submaximal social defeat experiment (see Fig. 1D). Three days after surgery, mice were subjected to two consecutive defeats on the same day and then tested for social interaction $24 \mathrm{~h}$ later. This submaximal defeat procedure has been validated previously to reveal prosusceptibility phenotypes following genetic manipulations (Krishnan et al., 2007; Vialou et al., 2010).

A second batch of mice was used to test for basal anxiety- and depressive-like behaviors (see Fig. $1 E-J$ ). A day after the surgery, mice were habituated with a $1 \%(\mathrm{w} / \mathrm{v})$ sucrose solution. The following day, mice could choose between a water bottle and a $1 \%$ sucrose solution bottle, switched daily. Sucrose solution intake for $24 \mathrm{~h}$ was measured during the fourth and fifth day after surgery and expressed as a percentage of the total amount of liquid ingested. Mice were tested in the openfield (day 3), elevated plus maze (day 4), social interaction (day 5 morning), and forced swim (day 5 afternoon) tests based on published protocols (Vialou et al., 2010). We have found that, with this order of testing, results on subsequent tests are not affected by previous ones (Krishnan et al., 2007). The activity of mice in the open field was recorded for 5 min using a videotracking system (Ethovision) under red light conditions. The elevated plus maze consisted of two straight intersecting runways positioned $60 \mathrm{~cm}$ above the floor and divided into two open and 
two enclosed arms. Mice were individually placed at the center of the maze and allowed to freely explore each arm for a period of $5 \mathrm{~min}$. In the open-field and elevated plus maze tests, time spent in the center and open arms, respectively, was used as an inverse index of anxiety-related responses. A one day forced swim test was conducted for a period of $5 \mathrm{~min}$. Increased time of immobility during the forced swim test was interpreted as a prodepression-like behavior. This 1 day test has been used extensively in mice and validated as a measure of predictive validity, in that antidepressant drugs reduce immobility times.

Finally, a separate group of mice were injected intra-mOFC with HSV$\Delta \mathrm{FosB}$ and tested for social interaction after a submaximal defeat (see Fig. $1 K)$.

HSV vectors were obtained from Rachael Neve (Massachusetts Institute of Technology). The genes of interest ( $\Delta$ FosB and GFP) are under a CMV promoter. These vectors have been extensively validated in prior publications (e.g., Maze et al., 2010).

Experiment 4: effects of chronic social stress on CCKB receptor levels in $m P F C$. At $24 \mathrm{~h}$ after the social interaction test, brains were quickly removed and serially sliced, and mPFC was rapidly dissected and frozen on dry ice (see Fig. 2A,B). RNA isolation, qPCR, and data analysis were performed as described previously (Maze et al., 2010; Vialou et al., 2010). RNA was isolated with TriZol reagent (Invitrogen) and was further purified with RNAeasy micro kits from QIAGEN. All RNA samples were determined to have $260 / 280$ and $260 / 230$ values $\geq 1$.8. Reverse transcription was performed using iScript (Bio-Rad). qPCR using SYBR Green (Quanta) was performed with an Applied Biosystems 7900HT RT PCR system with the following cycle parameters: $2 \mathrm{~min}$ at $95^{\circ} \mathrm{C} ; 40$ cycles of $95^{\circ} \mathrm{C}$ for $15 \mathrm{~s}, 59^{\circ} \mathrm{C}$ for $30 \mathrm{~s}$, and $72^{\circ} \mathrm{C}$ for $33 \mathrm{~s}$; and graded heating to $95^{\circ} \mathrm{C}$ to generate dissociation curves for confirmation of single PCR products. Data were analyzed by comparing $C_{t}$ values of the treatment condition (susceptible or resilient vs control mice, or HSV- $\Delta$ FosB vs HSV-GFP) with the $\Delta \Delta \mathrm{C}_{\mathrm{t}}$ method (Tsankova et al., 2006). qPCR primers are as follows: $\Delta$ FosB, forward, AGGCAGAGCTGGAGTCGGAGAT and reverse, GCCGAGGACTTGAACTTCACTCG; CCKB, forward, ACCCTTTATGCGGTGATCTTTC and reverse, ATGAGCACGTTTCC GCCAA; CCK, forward, AGCGCGATACATCCAGCAG and reverse, ACGATGGGTATTCGTAGTCCTC; GAPDH, forward, AGGTCGGTGTGAACGGATTTG and reverse, TGTAGACCATGTAGTTGAGGTCA.

Experiment 5: effects of $\triangle F o s B$ on $C C K B$ receptor and cFos levels. Mice were injected intra-PrL with HSV- $\Delta$ FosB. At $72 \mathrm{~h}$ after surgery, at the peak of viral overexpression, injection sites were dissected under a fluorescent microscope (see Fig. 2C). RNA isolation, qPCR, and data analysis were performed as described above. qPCR primers are as follows: c-fos, forward, AATCCGAAGGGAACGGAATAAGA and reverse, TGCAA CGCAGACTTCTCATCT.

Experiment 6: effects of $\triangle F$ Fos B blockade on stress-induced CCKB receptor levels and resilience. Adult mice were injected bilaterally with HSV-GFP or HSV- $\Delta$ JunD into PrL (see Fig. $2 D-F$ ). $\Delta$ JunD is an N-terminal truncated mutant of JunD that acts as a dominant-negative antagonist of $\Delta$ FosB. Mice were subjected to social defeat twice daily for $5 \mathrm{~d}$. This accelerated social defeat protocol, shortened to coincide with the period of maximal HSV transgene expression, has been used previously and shown to induce maximal levels of social avoidance (Covington et al., 2011). At $24 \mathrm{~h}$ after the last stress episode, mice were decapitated without anesthesia to avoid effects of anesthetics on neuronal protein levels. Infected tissue was removed in PBS-containing protease (Roche) and phosphatase (Sigma-Aldrich) inhibitors using a 15 gauge punch and immediately frozen on dry ice. Samples were homogenized by light sonication in modified RIPA buffer: $10 \mathrm{~mm}$ Tris base, $150 \mathrm{~mm}$ sodium chloride, 1 mm EDTA, 0.1\% SDS, $1 \%$ Triton X-100, 1\% sodium deoxycholate, $\mathrm{pH} 7.4$, and protease and phosphatase inhibitors as above. After addition of Laemmli's buffer, proteins were separated on $4-15 \%$ polyacrylamaide gradient gels (Criterion System; Bio-Rad), and Western blotting was performed using the Odyssey system (Li-Cor) according to the protocols of the manufacturer. Membranes were blotted with CCKB receptor antibody (1/1000, Acris, catalog \#AP01421PU-N). Another group of mice were injected with AAV- $\Delta$ JunD or AAV-GFP in PrL and then, 5 weeks after surgery to allow maximal transgene expression, the mice were submitted to the submaximal defeat protocol. They were tested for social interaction $24 \mathrm{~h}$ after the last defeat.

Experiment 7: effects of intra-mPFC CI-988, a CCKB antagonist, on social stress-induced social avoidance and anhedonia. Bilateral cannula ( $1.0 \mathrm{~mm}$ cannula to cannula distance, $1.8 \mathrm{~mm}$ anterior, injector -2.2 $\mathrm{mm}$ dorsal/ventral) targeting $\mathrm{mPFC}$ were implanted in susceptible mice (see Fig. 2G,H). A week after surgery, 10 ng of CI-988 was infused directly into $\mathrm{mPFC}$, targeting primarily PrL. Mice were then tested for their social interaction behavior. Sucrose preference was measured for the remaining 24 h. CI-988 (Tocris Bioscience) was dissolved in saline, aliquoted, and frozen. Final dilution was prepared on the day of the experiment. An additional experiment was performed in susceptible mice with CI-988 administered intraperitoneally $(2 \mathrm{mg} / \mathrm{kg}) 30 \mathrm{~min}$ before the social interaction test.

Experiment 8: effects of CCKB agonist on susceptibility to social stress and reversal by optogenetic stimulation of $m P F C$ projections to BLA or NAc. AAV-CaMKII-ChR2-EYFP or AAV-CaMKII-EYFP was injected into the right $\mathrm{mPFC}$, again targeting primarily $\operatorname{PrL}$ (see Fig. $3 A-G$ ). Five weeks later, optic fibers were implanted in right NAc (1.4 anterior/posterior, 2.6 lateral, $-4.7 \mathrm{dorsal} / \mathrm{ventral}$ at an angle of $25^{\circ}$ from the midline) or BLA $(-1.6$ anterior/posterior, 3.1 lateral, $-4.7 \mathrm{dorsal} /$ ventral with no angle from the midline). During the same surgical procedure bilateral cannula were implanted into mPFC (see above). Cannulae and fibers were secured to the skull with dental cement. Mice were then allowed 1 week to recover before the start of the behavioral experiments. Mice were subjected to submaximal defeat, then tested $24 \mathrm{~h}$ later for social interaction, directly followed by elevated plus maze and for sucrose preference for the remaining $24 \mathrm{~h}$. At $30 \mathrm{~min}$ before the social interaction test, half the mice were infused with CCK-8 $(10 \mathrm{ng})$ into $\mathrm{mPFC}$ while the other half received vehicle (saline). Mice were tested in pairs (a vehicle- and a CCK-8-treated mouse, with AAV-GFP or AAV-ChR2). CCK-8 (Sigma) was dissolved in saline, aliquoted, and frozen. Final dilution was prepared the day of the experiment.

Optical stimulations were performed according to published protocols (Covington et al., 2010). Optical fibers (Thor Laboratories) were chronically implanted and connected via a FC/PC adaptor to a $473 \mathrm{~nm}$ blue laser diode (Crystal Lasers, BCL-473-050-M). A stimulator (Agilent, \#33220A) was used to generate blue light pulses. During all stimulations, 40 ms bursts of $100 \mathrm{~Hz}$ ( $9.9 \mathrm{~ms}$ spike width) blue light pulses were delivered every 3 s to terminal regions in BLA or NAc over the duration of the social interaction test only, to mimic a burst-like pattern of cortical activity. The intensity of the optic fiber light was verified before each use, using a light sensor (Thor Laboratories, S130A), and light intensity was $\sim 15 \mathrm{~mW}$. This stimulation protocol, which was validated electrophysiologically previously (Covington et al., 2010), did not induce seizures based on behavioral observations and the absence of c-Fos expression outside of optogenetically stimulated regions (Covington et al., 2010).

Experiment 9: effects of CCKB agonist on MPFC neuronal activity as measured by c-Fos $m R N A$ levels. Bilateral cannulae were implanted on adult mice targeting the mPFC (see Fig. $3 H$ ). After a week of rest, mice were subjected to submaximal defeat and infused with CCK- $824 \mathrm{~h}$ later. $\mathrm{mPFC}$ punches were taken $30 \mathrm{~min}$ after the drug infusion, and samples prepared for mRNA analysis as described above.

Animal housing. Eight-week-old C57BL/6J male mice (The Jackson Laboratory) were used. All mice were habituated to the animal facility for at least 1 week before experimental manipulations and were maintained at $23^{\circ} \mathrm{C}-25^{\circ} \mathrm{C}$ on a $12 \mathrm{~h}$ light/dark cycle (lights on at 7:00 A.M.) with ad libitum access to food and water. Experiments were conducted in accordance with guidelines of the Society for Neuroscience and the Institutional Animal Care and Use Committee at Icahn School of Medicine at Mount Sinai.

Statistical analyses. Data displayed are expressed as mean \pm SEM (represented as error bars). One-way ANOVAs were used to compare means between control, susceptible, and resilient mice in immunohistochemical, biochemical, and behavioral analyses. One-way ANOVAs were used to compare means between GFP-controls and $\Delta$ FosB overexpression in PrL or IL in the open-field, elevated plus maze, forced swim, and sucrose preference tests. Two-way ANOVAs were used to compare means between GFP-controls, $\Delta$ FosB-PrL, and $\Delta$ FosB-IL in the social interaction 


\begin{tabular}{|c|c|c|c|}
\hline Structure & Control & Susceptible & Resilient \\
\hline $\mathrm{OFC}$ & $37.5 \pm 1.1$ & $94.4 \pm 17.1^{* *}$ & $114.5 \pm 5.7^{* *}$ \\
\hline PrL & $38.1 \pm 7.9$ & $72.9 \pm 3.4^{* *}$ & $59.7 \pm 8.3$ \\
\hline IL & $33.4 \pm 8.4$ & $56.4 \pm 7.6$ & $72.1 \pm 6.7^{* *}$ \\
\hline NAc shell & $256.1 \pm 35.3$ & $459.6 \pm 15.1^{* * *}$ & $581.5 \pm 23.7^{* * * * \#}$ \\
\hline NAc core & $281.7 \pm 45.0$ & $386.7 \pm 14.3$ & $592.2 \pm 47.1^{* * * * \#}$ \\
\hline $\mathrm{CPu}$ & $99.0 \pm 22.5$ & $127.5 \pm 18.9$ & $176.0 \pm 10.3^{*}$ \\
\hline LSd & $34.0 \pm 8.1$ & $64.5 \pm 18.2$ & $84.0 \pm 15.2$ \\
\hline LSv & $89.0 \pm 16.8$ & $268.0 \pm 37.7^{*}$ & $196.8 \pm 43.8$ \\
\hline BNSTd & $20.0 \pm 3.0$ & $64.5 \pm 9.3^{* *}$ & $46.5 \pm 7.4$ \\
\hline BNSTV & $28.5 \pm 5.1$ & $59.3 \pm 6.4$ & $77.0 \pm 26.4$ \\
\hline DG & $315.1 \pm 41.0$ & $306.4 \pm 66.6$ & $538.9 \pm 63.8^{\#}$ \\
\hline CA1 & $10.9 \pm 4.7$ & $2.9 \pm 1.9$ & $6.1 \pm 3.7$ \\
\hline CA3 & $59.2 \pm 14.4$ & $51.0 \pm 7.9$ & $113.9 \pm 26.1$ \\
\hline BLA & $55.6 \pm 5.9$ & $71.0 \pm 15.2$ & $108.7 \pm 7.3^{*}$ \\
\hline BMA & $79.8 \pm 11.6$ & $90.4 \pm 22.8$ & $137.3 \pm 36.5$ \\
\hline CeA & $61.2 \pm 16.7$ & $45.7 \pm 9.9$ & $50.1 \pm 12.2$ \\
\hline SNC & $8.0 \pm 2.9$ & $9.8 \pm 5.4$ & $5.5 \pm 1.4$ \\
\hline VTA & $11.0 \pm 3.9$ & $23.3 \pm 6.5$ & $18.5 \pm 4.2$ \\
\hline PAG & $18.7 \pm 2.2$ & $33.6 \pm 3.7^{*}$ & $38.1 \pm 4.8^{*}$ \\
\hline DR & $8.0 \pm 2.2$ & $30.3 \pm 3.7^{* *}$ & $25.8 \pm 3.9^{*}$ \\
\hline LC & $26.7 \pm 7.4$ & $88.6 \pm 24.7$ & $92.2 \pm 23.2$ \\
\hline
\end{tabular}

$\mathrm{CPu}$, Caudate-putamen; LSd/v, lateral septum dorsal/ventral; BNST, bed nucleus of stria terminalis; DG, dentate gyrus; CA1/3, cornu ammonis area 1/3; BMA, basomedial amygdala; CeA, central nucleus of the amygdala; SNc, subtantia nigra pars compacta; VTA, ventral tegmental area; DR, dorsal raphe; LC, locus ceruleus.

${ }^{*} p<0.05$, compared with controls.

${ }^{* *} p<0.01$, compared with controls.

${ }^{* * *} p<0.001$, compared with controls.

" $p<0.05$, compared with susceptible mice.

test. Two-way ANOVAs were used to compare CCK-8 effects with or without optogenetic stimulation in all behavioral experiments, as well as the effect of $\Delta$ FosB overexpression or CI-988 infusion on social avoidance. When appropriate, post hoc analyses were conducted using a Bonferroni post hoc test. Student's $t$ tests were used to compare means for the effect of CI-988 infusion on sucrose preference and forced swim tests, and of CCK- 8 on $c$-Fos mRNA levels. Differences between experimental conditions were considered statistically significant when $p \leq 0.05$.

\section{Results}

\section{Brain-wide mapping of $\Delta$ FosB induction by chronic social defeat stress}

We first investigated $\Delta$ FosB induction by immunohistochemistry in control, susceptible, and resilient mice, after a course of chronic (10 d) social defeat stress, with a focus on forebrain and midbrain regions implicated previously in stress responses. Animals were analyzed $24 \mathrm{~h}$ after the last defeat episode. Chronic social stress induces $\triangle \mathrm{FosB}$ in numerous brain areas with distinct patterns observed between resilient and susceptible mice. As shown in Table 1 and Figure 1A, IL, BLA, dentate gyrus of hippocampus, dorsal striatum, and NAc core showed preferential activation in resilient mice; such results in NAc are consistent with published findings (Vialou et al., 2010). In striking contrast, susceptible mice showed greater induction in PrL, lateral septum, and bed nucleus of stria terminalis. Several brain regions showed comparable $\Delta$ FosB induction in susceptible and resilient mice; these included orbitofrontal cortex (OFC, another area of PFC), NAc shell, dorsal raphé, and periaqueducal gray (PAG).

To identify the neuronal subtype displaying $\triangle$ FosB induction in cortical regions, GAD2-tdTomato mice were subjected to chronic social defeat stress. $\triangle$ FosB immunoreactivity in susceptible mice was undetectable in GABAergic neurons (Fig. $1 B$ ), which confirms earlier findings of specific induction of $\Delta$ FosB in cortical pyramidal neurons after other forms of chronic stress (Perrotti et al., 2004). In nondefeated control mice, baseline $\Delta$ FosB levels across brain regions were similar to those reported in previous studies (Perrotti et al., 2004, 2008) with much higher basal levels in the NAc and dorsal striatum compared with any other region, with the one exception of dentate gyrus, which displayed levels comparable with those in striatal regions (Table 1).

\section{$\triangle$ FosB in mPFC promotes susceptibility to stress}

To follow-up these findings, we focused on PrL because we had shown previously that optogenetic activation of this region exerted antidepressant-like effects in the social defeat paradigm (Covington et al., 2010). To test the functional consequences of $\Delta$ FosB induction in this brain region, we virally overexpressed $\Delta$ FosB in PrL of control mice (Fig. 1C) and subjected them to a submaximal course of social defeat stress, which does not induce social avoidance in normal animals. Mice overexpressing $\Delta$ FosB in PrL were more susceptible to social defeat than GFP-injected control mice in that they showed social avoidance behavior after submaximal social defeat (interaction, $F_{(2,38)}=2.847, p>0.05$, main effect of virus, $F_{(2,38)}=6.013, p<0.05$; Bonferroni post test $t=2.447, p<0.05$ ) (Fig. $1 D$ ). These mice also showed increased immobility in a 1 day forced swim test $\left(F_{(2,31)}=6.448, p<0.05\right.$; Bonferroni post test $t=3.518, p<0.05$ ) (Fig. $1 E$ ), an effect opposite to that produced by antidepressant drugs. In contrast, $\Delta$ FosB overexpression in PrL did not alter several baseline measures of anxiety-like behavior, sucrose preference, social interaction, or locomotor activity (Fig. $1 F-J$ ). Together, these findings support the hypothesis that the selective induction of $\Delta \mathrm{FosB}$ in PrL of susceptible mice contributes to vulnerability to stress and its deleterious consequences. In contrast, $\Delta \mathrm{FosB}$ overexpression in another region of mPFC, IL, had no effect on baseline emotional behaviors or on responses to social defeat stress (Fig. $1 D-$ $J$ ), whereas $\Delta$ FosB overexpression in medial OFC trended toward promoting resilience to chronic social defeat, although this effect did not reach statistical significance (interaction, $F_{(1,31)}=1.741$, $p>0.05$, main effect of interaction time, $F_{(1,31)}=14.170, p<$ 0.05 ; Bonferroni post test $t=3.860, p<0.05$ within GFP group; $t=1.960, p<0.05$ within $\Delta$ FosB group; effect of virus, $t=2.447$, $p<0.05$ ) (Fig. $1 K$ ).

\section{$\triangle$ FosB promotes CCKB induction in mPFC}

A large body of evidence supports the notion that CCK, an abundant neuropeptide in brain, plays an essential role in neurobiological mechanisms of stress and anxiety (Rotzinger and Vaccarino, 2003). In particular, release of CCK in mPFC during social stress in rats is associated with anxiety-related behaviors (Becker et al., 2001). Although the involvement of CCK in human depression remains unclear, recent evidence points to its role in social defeat-induced depression-like behavior in rats (Becker et al., 2008). We thus hypothesized that alterations in levels of CCK or its CCKB (also known as CCK2) receptor in MPFC might contribute to differences between susceptible and resilient mice. At $48 \mathrm{~h}$ after the final defeat episode, CCKB mRNA levels were decreased in mPFC of resilient mice only $\left(F_{(2,18)}=8.084, p<\right.$ 0.01 ; Bonferroni post test, $t=3.104, p<0.05$ vs control; $t=$ $5.113, p<0.01$ vs susceptible) (Fig. $2 A$ ). No difference was observed in CCK mRNA levels in either susceptible or resilient mice (data not shown). We observed an increase in $\triangle F o s B$ mRNA levels only in susceptible mice consistent with the protein data reported above $\left(F_{(2,18)}=5.246, p<0.01\right.$; Bonferroni post test $t=$ $3.336, p<0.05$ vs susceptible; $t$ test $t_{(12)}=2.138, p<0.05$ vs control) (Fig. $2 B$ ). Because $\Delta$ FosB regulates the transcription of 
A

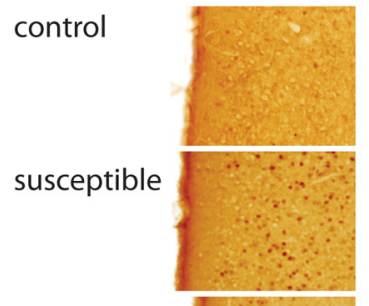

resilient

B

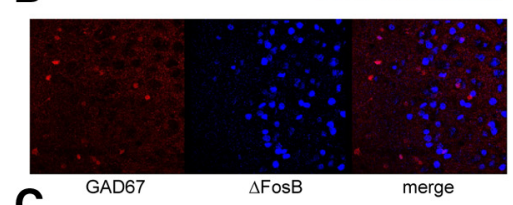

C

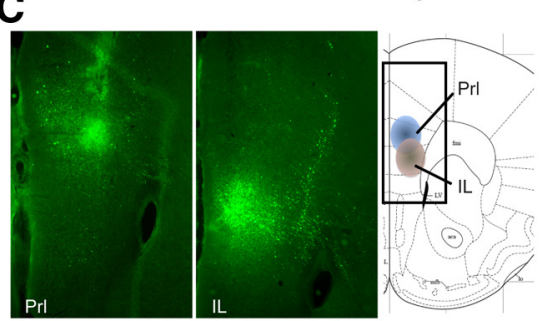

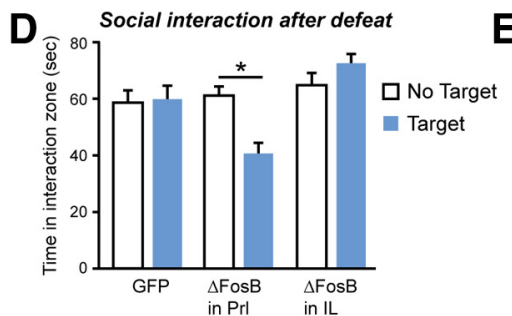
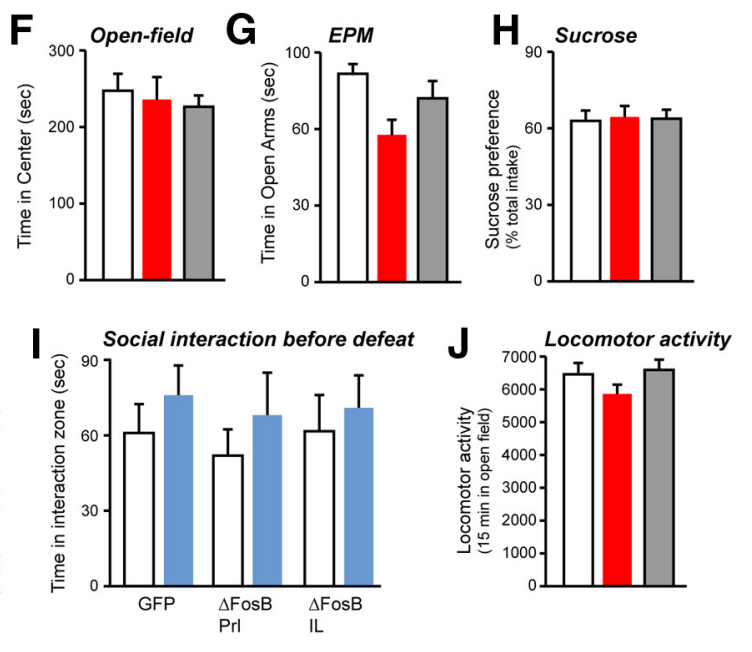

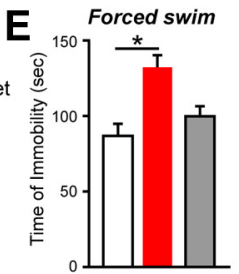

口GFP

$\triangle \mathrm{FosB}-\mathrm{PrL}$

$\square \triangle$ FosB-IL

Figure 1. $\triangle F$ FosB induction in $\mathrm{mPFC}$ promotes susceptibility to stress. $A$, Representative photomicrographs of $\triangle \mathrm{FosB}$ immunohistochemistry in $\mathrm{mPFC} 24 \mathrm{~h}$ after the last of 10 social defeat episodes. $\boldsymbol{B}$, Induction of $\Delta$ FosB does not occur in GABAergic interneurons in PrL. C, Representative photomicrograph of HSV- $\Delta$ FosB injection into PrL (left) and IL (right). D, Overexpression of $\Delta$ FosB in PrL promotes social avoidance to submaximal defeat stress $\left(n=7-11 ;{ }^{*} p<0.05\right.$, two-way ANOVA, compared with "no target"), and immobility in the forced swim test $(\boldsymbol{E})\left(n=8-10 ;{ }^{*} p<\right.$ 0.05 , one-way ANOVA, compared with "GFP") but does not affect basal measures of anxiety $(\boldsymbol{F}, \boldsymbol{G})$, anhedonia $(\boldsymbol{H})$, social interaction with no stress $(\boldsymbol{I})$, or locomotor activity $(\boldsymbol{J})(n=7-11)$. Overexpression of $\Delta$ FosB in IL had no discernible effects in these assays $(\boldsymbol{D}-\boldsymbol{J})(n=7-11) . K$, Overexpression of $\Delta$ FosB in $\mathrm{m} 0 \mathrm{FC}$ did not significantly reverse social avoidance induced by chronic social defeat stress $\left(n=8-10 ;{ }^{*} p<0.05\right.$, two-way ANOVA, compared with "no target," \# $p<0.05, t$ test vs GFP).

A

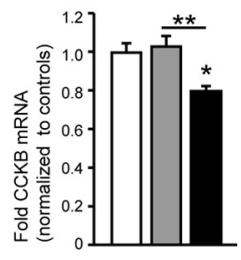

D

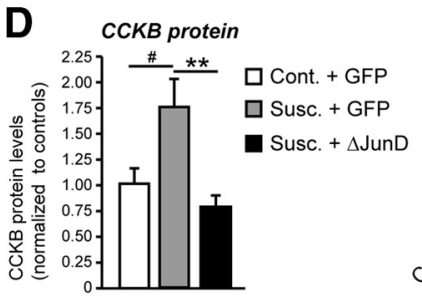

B

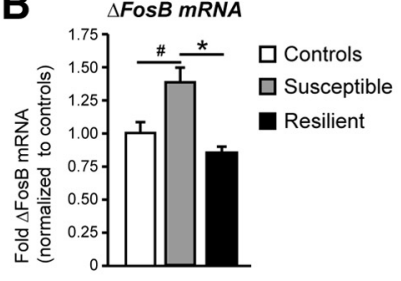

E

C

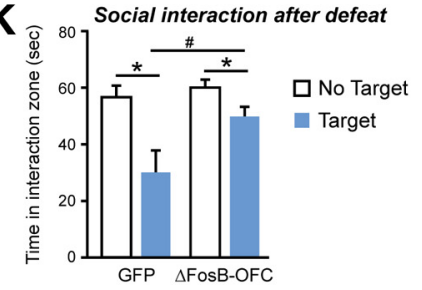

Figure 2. Blockade of the CCKB receptor has a proresilience, antidepressant-like effect. $A$, Social defeat decreases CCKB receptor levels in $\mathrm{mPFC}$ only in resilient mice $(n=8-10) .{ }^{*} p<0.05$, compared with control (one-way ANOVA). ${ }^{* *} p<0.05$ ( $t$ test). $B, \Delta$ FosB mRNA was only induced in susceptible mice $(n=8-10) .{ }^{*} p<0.05$ (one-way ANOVA). ${ }^{\#} p<0.05$ ( $t$ test). $C$, Overexpression of $\Delta$ FosB in PrL of susceptible mice upregulates CCKB levels and downregulates c-Fos levels in this brain region $(n=7-11) .{ }^{*} p<0.05$ ( $t$ test vs GFP). ${ }^{* *} p<0.01$ ( $t$ test vs GFP). D, HSV-mediated expression of $\Delta$ JunD in PrL blocked social defeat-induced CCKB protein levels in this region $(n=7)$. ${ }^{* *} p<0.05$ (one-way ANOVA). ${ }^{\#} p<0.05$ ( $t$ test vs control). $\boldsymbol{E}$, Western blots of virus-injected PrL shown in $\boldsymbol{D} . \boldsymbol{F}, \Delta$ JunD promoted resilience to social defeat-induced avoidance $(n=9)$. ${ }^{\#} p=0.05$ ( $t$ test vs GFP). $\boldsymbol{G}, \boldsymbol{H}$, Infusion of the CCKB receptor antagonist $\mathrm{Cl}-988$ (10 ng) into PrL of susceptible mice reverses the social avoidance $\left(n=6 ;{ }^{*} p<0.05\right.$, two-way ANOVA) and sucrose preference deficit induced by social defeat $\left(n=6\right.$; ${ }^{*} p<0.05$, t test vs vehicle).

numerous genes (McClung and Nestler, 2003; Winstanley et al., 2007), we considered the possibility that it might regulate CCKB mRNA expression. To address this question, we first overexpressed $\Delta$ FosB in PrL and found that this manipulation upregulates CCKB mRNA levels in this region $\left(t_{(12)}=2.012, p<0.05\right.$ vs GFP) (Fig. 2C). Interestingly, we also found a decrease in $c$-Fos
mRNA levels after $\Delta$ FosB overexpression $\left(t_{(11)}=3.382, p<0.01\right)$ (Fig. 2C). These findings further suggest that $\Delta$ FosB induction in PrL of susceptible mice is an active mechanism of susceptibility by preventing the suppression of CCKB seen in resilient mice.

To further strengthen these observations, we overexpressed $\Delta \mathrm{JunD}$, a $\Delta$ FosB binding partner that lacks its transactivation 
domain and thereby acts as a dominant negative antagonist, and determined its effect on stress-induced CCKB expression. We confirmed that chronic social defeat stress increased CCKB protein levels in PrL of susceptible mice $\left(t\right.$ test $t_{(12)}=2.289, p<0.05$ vs control) (Fig. $2 D, E)$. Moreover, such induction was completely blocked by $\Delta$ JunD overexpression in this region $\left(F_{(2,20)}=\right.$ 6.306, $p<0.01$, Bonferroni post test $t=3.615, p<0.01$ ) (Fig. $2 D, E)$, supporting the hypothesis that $\Delta$ FosB mediates stressinduced CCKB expression. Furthermore, blockade of $\Delta$ FosB activity in PrL, via local $\Delta$ JunD expression, also promoted resilience to defeat stress ( $t$ test $t_{(16)}=2.114, p=0.05$ vs control) (Fig. $2 F$ ). The mechanism underlying the downregulation of CCKB in resilient mice remains to be elucidated.

\section{Role of CCKB in resilience and susceptibility to stress}

To directly test the role of CCKB regulation in PrL in mediating susceptibility versus resilience, we infused the selective CCKB receptor antagonist CI-988 (10 ng) directly into this brain region of susceptible mice. CI-988 effectively antagonizes CCKB receptors in vivo because it exhibits nanomolar affinity and high selectivity for the CCKB receptor subtype (Noble et al., 1999). Blockade of CCKB activity strongly increased social interaction (Fig. $2 G$ ) (interaction, $F_{(1,20)}=7.795, p<0.05$; drug $F_{(1,20)}=$ 5.38, $p<0.05$, Bonferroni post test $t=3.615, p<0.01)$. CI-988 infusion also reversed the deficit in sucrose preference observed in susceptible mice $\left(t_{(8)}=2.681, p<0.05\right.$ ) (Fig. $2 H$ ). Both behavioral results indicate that blockade of CCK action in PrL exerts potent antidepressant-like effects. Interestingly, when administered intraperitoneally, CI-988 was ineffective in reversing social avoidance (data not shown).

To test the converse, that activation of CCKB in PrL could mediate the social avoidance and decreased sucrose preference induced by chronic social defeat stress, we examined the effect of local infusion of CCK-8 (10 ng), the predominant form of CCK in brain, on depression- and anxiety-related behaviors. The dose of the drug was chosen based on previous results in the literature (De Witte et al., 1987; Rotzinger and Vaccarino, 2003; Zanoveli et al., 2004). Mice were exposed to submaximal social defeat stress $24 \mathrm{~h}$ before behavioral testing (Fig. $3 \mathrm{~A}$ ). CCK-8, infused $30 \mathrm{~min}$ before testing, was sufficient to induce social avoidance in the social interaction test as well as a decrease in time spent in the open arms in the elevated plus maze (SI: BLA, interaction, $F_{(1,22)}=0.79, p>0.05$; main effect of drug, $F_{(1,22)}=11.75, p<0.05$; Bonferroni post test $t=2.957$, $p<0.05$; NAc: interaction, $F_{(1,26)}=6.688, p<0.05$, Bonferroni post test $t=2.816, p<0.05$; EPM: BLA, interaction, $F_{(1,22)}=8.0, p<0.01$; Bonferroni post test $t=2.509, p<0.05$ drug effect; $t=2.528, p<0.05$ virus effect; NAc, $t$ test $t_{(17)}=$ $1.961 ; p<0.05$ drug effect within eYFP group) (Fig. $3 B-E$, left). No differences were observed in sucrose preference (Fig. $3 F, G$, left). Finally, CCK-8 infusion had no effect on the behavior (social interaction and elevated plus maze) of naive nondefeated mice in these assays (data not shown). These results demonstrate that the $\Delta$ FosB-mediated increase in CCKB activity in PrL of susceptible mice, compared with resilient mice, contributes to some of the stress-induced behavioral deficits exhibited by these animals.

\section{Blockade of CCK-induced susceptibility to stress by activation of cortical projections to BLA versus NAc}

Decreased $\mathrm{mPFC}$ neural activity correlates with depression-like behaviors in mice, with optogenetic stimulation of mPFC neurons of susceptible mice producing antidepressant-like effects
(Covington et al., 2010). We thus hypothesized that CCK might act in PrL by inhibiting neuronal activity and thereby causing depression-like behavior. Consistent with this hypothesis, we observed a decrease in $c$-Fos mRNA levels in PrL in response to CCK infusion into this brain region $\left(t_{(13)}=2.235, p<0.05\right)($ Fig. $3 H)$.

We next hypothesized that optogenetic stimulation of $\mathrm{mPFC}$ exerts its antidepressant actions by opposing the effects of CCK on neuronal activity. In testing this hypothesis, we investigated the subcortical structures mediating the anxiogenic- and prodepression-like effects of CCK. Pyramidal neurons of the mPFC project heavily to the NAc and BLA, two limbic structures implicated in behavioral responses to stress. Altered activity of both brain regions has been shown to play an essential role in the expression of anxiety- and depression-like behaviors (Vialou et al., 2010; Tye et al., 2011). We therefore tested whether stimulation of glutamatergic projections from PrL to NAc or to BLA would oppose the deleterious effects of CCK microinfusion into PrL (Fig. 3A). We injected AAV-CaMKII-ChR2-EYFP, or AAVCaMKII-EYFP as a control, into PrL. The CaMKII promoter is known to target viral expression to glutamatergic pyramidal neurons in cortical regions. We then allowed sufficient time (6 weeks) for the transgenes to be transported to the nerve terminals of these pyramidal neurons in NAc and BLA (Fig. 3I). Mice received submaximal social defeat; 24 h later, we infused CCK-8 into $\operatorname{PrL}$ and, $30 \mathrm{~min}$ after that, social interaction was measured during optogenetic stimulation of glutamatergic terminals in NAc or BLA. Immediately after the social interaction test, mice were evaluated in the elevated plus maze to assess anxiety-related behavior and then for sucrose preference to assess anhedonia.

Optogenetic stimulation of PrL glutamatergic projections to NAc fully reversed the social avoidance induced by intraPrL CCK-8 (interaction, $F_{(1,26)}=6.688, p<0.05$, no drug effect in ChR2 group) (Fig. $3 C$ ). In contrast, such PrL to NAc stimulation had no effect on anxiety-like behavior as measured in the elevated plus maze (Fig. $3 E$ ); however, such stimulation increased sucrose preference compared with unstimulated mice (interaction, $F_{(1,20)}=5.77, p<0.05$; Bonferroni post test $t=2.998, p<0.05$ stimulation effect within CCK-8 treated animals) (Fig. $3 G$ ).

A very different behavioral pattern was seen with optogenetic stimulation of PrL glutamatergic projections to BLA. Such stimulation did not prevent the social avoidance induced by intra-PrL CCK-8 infusion (interaction, $F_{(1,22)}=0.79, p>0.05$; main effect of drug, $F_{(1,22)}=11.75, p<0.05$; no effect in stimulated group, $t$ test $t_{(12)}=2.054, p<0.05$ ) (Fig. 3B). However, stimulation of BLA afferents exerted an anxiolytic-like effect as indicated by increased time spent in the open arms of the elevated plus maze (interaction, $F_{(1,22)}=8.0, p<0.01$; Bonferroni post test $t=$ 2.528, $p<0.05$ virus effect within CCK-8 treated groups) (Fig. $3 D$ ). Stimulation of glutamatergic projections to BLA had no significant effect on sucrose preference (interaction, $F_{(1,22)}=$ 2.08, $p>0.05$ ) (Fig. 3F).

\section{Discussion}

Results of the present study provide evidence of molecular adaptations occurring in PrL that underlie susceptibility to social stress. We show induction of $\Delta$ FosB in this $\mathrm{mPFC}$ subregion after chronic social defeat stress, where $\Delta$ FosB overexpression promotes stress susceptibility. We identified the CCKB receptor as one target gene regulated by $\Delta$ FosB in PrL, apparently inducing $\mathrm{CCKB}$ protein in susceptible mice and preventing the downregulation of $\mathrm{CCKB}$ expression that occurs selectively in resilient mice. We showed further that infusion of a CCK agonist into PrL 


\section{A Experimental timeline}
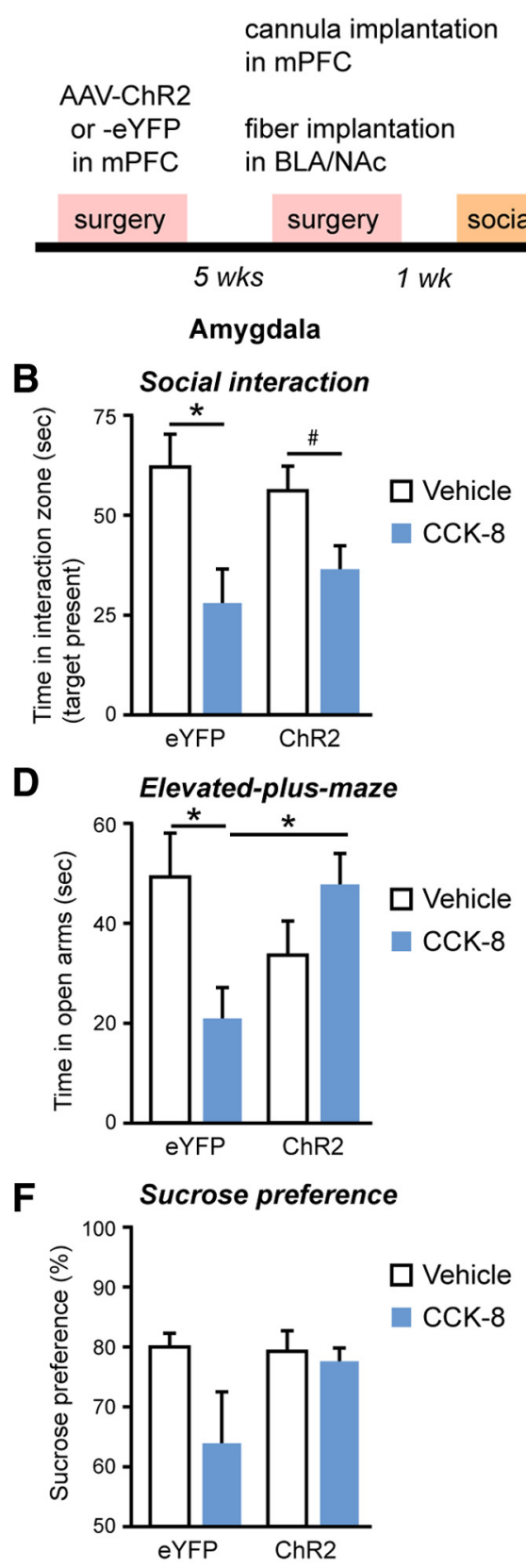

$$
\text { CCK-8 I }
$$

vehicle infusion

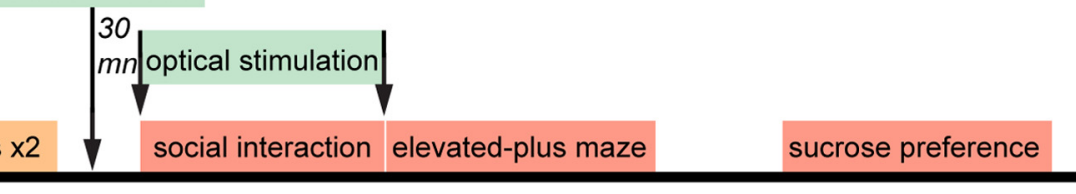

5 min 2-5 hrs

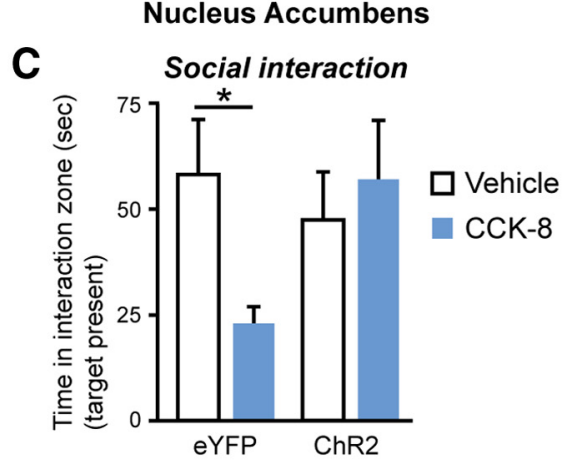

E

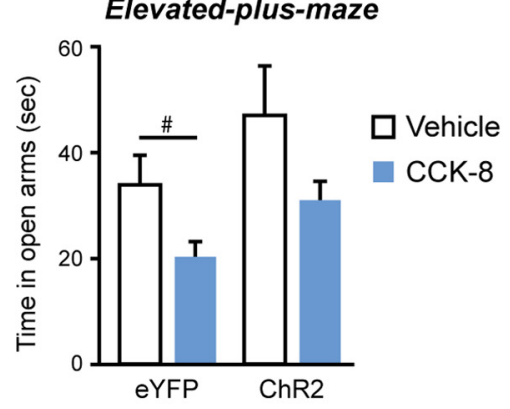

G

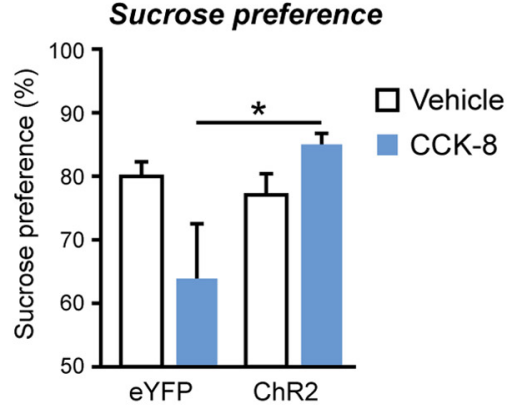

H

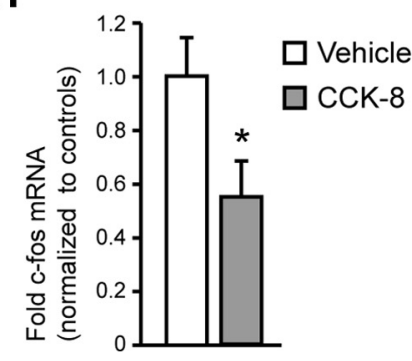

I

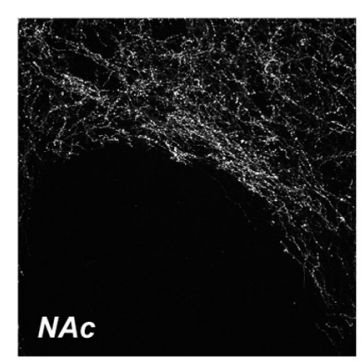

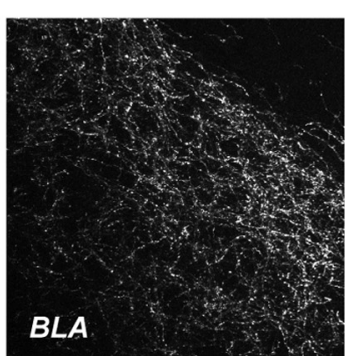

Figure 3. CCK-8-induced stress susceptibility depends on specific cortical projections. $\boldsymbol{A}$, At $24 \mathrm{~h}$ after submaximal social defeat and $30 \mathrm{~min}$ after CCK-8 infusion, $\mathrm{mPFC}$ projection regions were laser-stimulated during a test for social interaction. CCK-8 infusion into the PrL induced social avoidance $(\boldsymbol{B}, \boldsymbol{C})$, reduced exploratory behaviors $(\boldsymbol{D}, \boldsymbol{E})$, and decreased sucrose preference $(\boldsymbol{F}, \boldsymbol{G})(\boldsymbol{n}=$ $6-8) .{ }^{*} p<0.05$ (two-way ANOVA). ${ }^{\#} p<0.05$, compared with vehicle ( $t$ test). $\boldsymbol{H}$, CCK-8 infusion decreased $c$-Fos mRNA levels in mPFC, suggesting decreased neuronal activity $(n=7$ or 8$) .{ }^{*} p<$ 0.05 , compared with vehicle ( $t$ test). $I$, Representative photomicrograph of ChR2-GFP expression in two mPFC projections areas, NAc (left) and BLA (right), 6 weeks after injection into PrL. Optogenetic stimulation of cortical projections to $\mathrm{BLA}(\boldsymbol{B}-\boldsymbol{F})$ or NAc $(\boldsymbol{C}-\boldsymbol{G})$ had opposite effect on measures of social avoidance, sucrose preference, and anxiety-like behavior $(n=6-8)$. ${ }^{*} p<0.05$ (two-way ANOVA). 
promotes depression- and anxiety-like behavioral abnormalities in response to social stress, whereas blockade of CCKB receptor activity in this region of susceptible mice blocks these effects. We next used optogenetic tools to identify the microcircuitry involved in the proanxiety- vs prodepression-like actions of CCK in PrL. Although cortico-NAc glutamatergic projections mediate reward deficits evidenced by social avoidance and reduced sucrose preference, this microcircuit does not influence the anxiogenic effects of CCK infused into PrL. Conversely, cortical projections to BLA mediate the manifestation of anxiety-related behaviors but have no effect on social stress-induced social avoidance or sucrose preference deficits. Together, these data show that alterations in PrL function after chronic social defeat stress mediate numerous behavioral deficits via specific subcortical projections.

\section{$\triangle$ FosB: mapping a limbic stress network and role in mPFC}

$\Delta$ FosB immunohistochemistry identifies neurons affected by chronic stress with single-cell resolution and has been used for mapping stress-regulated neuronal circuitry (Perrotti et al., 2004; Nikulina et al., 2008; Lehmann and Herkenham, 2011). We used this methodology to show that chronic social defeat stress induces $\Delta$ FosB in several brain areas with distinct patterns between resilient and susceptible groups, with some regions showing induction in resilient mice only, others in susceptible mice only, and still others under both conditions (Table 1). Previous work demonstrated that $\Delta$ FosB induction in NAc or ventral PAG promotes resilience to chronic stress and contributes to antidepressant responses (Berton et al., 2007; Vialou et al., 2010).

Induction of $\Delta$ FosB in PrL of susceptible mice, coupled with previous findings that optogenetic stimulation of this region exerts antidepressant effects (Covington et al., 2010), prompted us to study the influence of $\Delta \mathrm{FosB}$ in this cortical region. Opposite to findings in NAc and ventral PAG, we found that $\triangle$ FosB in PrL promotes susceptibility to chronic social defeat stress and produces a prodepression-like effect in the forced swim test, without affecting anxiety-like behavior or sucrose preference. In contrast to $\operatorname{PrL}$, we found no effect of $\Delta \mathrm{FosB}$ overexpression in the nearby IL. A recent study found elevated levels of $\Delta F$ FosB in IL in resilient mice and implicated this subregion in resilience to social stress (Lehmann and Herkenham, 2011). Further studies are thus needed to address differential roles for these two MPFC subregions, which have been shown to produce opposite effects in other behavioral domains (Sierra-Mercado et al., 2011; BurgosRobles et al., 2013; Richard and Berridge, 2013). We previously reported that depressed humans display lower levels of $\Delta$ FosB in NAc examined postmortem (Vialou et al., 2010), whereas higher levels of $\triangle F$ FosB have been shown in dorsolateral PFC (Brodmann area 46) of depressed humans (Teyssier et al., 2011). Other cortical regions were not examined in the latter study. In any event, these findings together support region-specific abnormalities in $\Delta$ FosB expression in human depression, where the transcription factor exerts very different effects on stress vulnerability. It would be interesting in future studies to examine the influence of $\Delta \mathrm{FosB}$ in numerous other brain regions where it is induced (Table 1) on stress responses.

One mechanism by which $\Delta$ FosB induction in PrL might contribute to depression-like behavior is via suppression of PrL activity. $\triangle \mathrm{Fos} B$ has been shown to suppress AMPA glutamate responses, and $c$-Fos expression, in NAc medium spiny neurons (Renthal et al., 2008; Vialou et al., 2010; Grueter et al., 2013). Likewise, we found a decrease in $c$-Fos expression after $\Delta$ FosB overexpression in PrL. Thus, $\Delta$ FosB induction in PrL could be responsible for reduced neuronal activity seen in this region after chronic social defeat stress. Such decreased tone of PrL over its subcortical targets, such as BLA and NAc, would be expected to enhance fear expression and the inability to extinguish emotional responses to stress (Fales et al., 2008, 2009). Moreover, mPFC lesions induce sensitized stress responses and deficits in fear extinction (Holson, 1986; Silva et al., 1986; Diorio et al., 1993; Milad and Quirk, 2002), suggesting that stress-induced impairment of $\mathrm{mPFC}$, mediated partly via $\triangle \mathrm{FosB}$ induction, could contribute to depression and other stress-related disorders (Choi et al., 2012).

\section{Role of CCK in stress vulnerability}

We provide evidence that the CCKB receptor is a target of $\triangle \mathrm{FosB}$, such that $\Delta \mathrm{FosB}$ induction in PrL of susceptible mice only is one mechanism through which $\Delta$ FosB exerts its prodepression-like effects in this region. Although the specific actions of CCK in mPFC circuitry remain unclear, in rodents CCK is localized within GABAergic interneurons (Somogyi et al., 1984). It is thought to suppress the activity of cortical pyramidal neurons by enhancing local GABA release and acting directly on CCKB receptors expressed by pyramidal neurons (Yaksh et al., 1987; Benoliel et al., 1992; Pérez de la Mora et al., 1993; Gallopin et al., 2006). Thus, CCKergic neurotransmission could contribute to the reduced PrL activity noted above.

CCK is an anxiogenic agent, with systemic administration of CCKB agonists inducing panic attacks in healthy volunteers. Patients predisposed to panic attacks become hypersensitized after CCK exposure (de Montigny, 1989; Bradwejn et al., 1991). Several studies have confirmed CCK's anxiogenic effects in rodents (Rotzinger and Vaccarino, 2003). CCK release in mPFC during defeat stress in rats is associated with anxiety-related behaviors (Becker et al., 2001); PrL and IL subregions were not differentiated in this study. More recently, systemic, chronic blockade of CCKB with CI-988 exerted antidepressant-like effects in rats (Becker et al., 2008). CI988 normalized immobility time in the forced swim test. It also prevented hypothalamic-pituitary-adrenal axis hyperactivity, reduced hippocampal volume and cell proliferation, and reduced sucrose preference normally evoked by social defeat. Here, we confirm these results by showing an antidepressant-like effect of CI-988 infused into PrL of susceptible mice, although a single systemic injection did not mimic this effect.

In addition to the acute actions of CCK in PrL, we identified decreased levels of CCKB mRNA in resilient mice, which could be a molecular adaptation underlying resilience. Indeed, alterations in CCKergic tone, specifically CCKB levels, constitute an important mechanism for the expression of anxiety. Transgenic mice overexpressing CCKB in forebrain show heightened anxiety and fear responses (Chen et al., 2006). Our finding of altered CCKB levels between resilient and susceptible mice might contribute to the phenotypic differences in anxiety and depressive-like behavior. Here, we demonstrate the PrL as a critical anatomical substrate for the anxiogenic and prodepressant effects of CCK in the context of social stress. Nevertheless, several other brain regions are involved in CCK's behavioral actions, including BLA, hippocampus, NAc, and PAG (De Witte et al., 1987; Belcheva et al., 1994; Noble and Roques, 1999; Zanoveli et al., 2004; Rezayat et al., 2005). Also, we found an increase in CCKB protein levels, but not mRNA levels, in mPFC of susceptible animals. These findings underscore that, although mRNA levels often correlate with protein levels, this is not necessarily the case (Gygi et al., 1999).

Our optogenetic experiments demonstrate that increasing activity of glutamatergic projections from PrL to NAc or to BLA antagonizes the effects of CCK in PrL. Further studies are needed 
to establish that this effect of optogenetic stimulation is mediated by the same PrL neurons that are controlled by CCK. Interestingly, our data reveal distinct roles of these two microcircuits in mediating different domains of behavioral abnormalities. The cortico-NAc projection controls anhedonia and reward; the fact that it regulates social avoidance confirms that this symptom is more a reflection of decreased motivation and reward for social behavior and not of increased social anxiety. This conclusion is consistent with the inability of benzodiazepines to correct this abnormality (Berton et al., 2006), and with the recent demonstration that mPFC stimulation of NAc increases reward and motivation for drugs of abuse (Britt et al., 2012). In contrast, the cortico-BLA projection controls anxiety-related symptoms, consistent with a large literature in rodents and humans (see above).

In conclusion, results of the present study identify a pattern of limbic brain regions implicated in susceptible and resilient animals, and demonstrate alterations in PrL that promote susceptibility. These alterations involve induction of $\Delta$ FosB and its induction of the CCKB receptor. In contrast, blockade of CCK actions in PrL promotes antidepressant- and anxiolytic-like effects. We also establish the subcortical targets of these cortical pyramidal neurons that mediate these actions, with a cortico-NAc circuit essential for depression-related behaviors, and a cortico-BLA circuit essential for anxiety-related behaviors. Whereas clinical studies of CCKB antagonists in depressed patients in the 1990s did not yield promising results, the present findings suggest the value of revisiting the therapeutic potential of such agents in subsets of patients exposed to high levels of stress.

\section{References}

Akirav I, Maroun M (2007) The role of the medial prefrontal cortexamygdala circuit in stress effects on the extinction of fear. Neural Plast 2007:30873. CrossRef Medline

Barbas H, Blatt GJ (1995) Topographically specific hippocampal projections target functionally distinct prefrontal areas in the rhesus monkey. Hippocampus 5:511-533. CrossRef Medline

Becker C, Thièbot MH, Touitou Y, Hamon M, Cesselin F, Benoliel JJ (2001) Enhanced cortical extracellular levels of cholecystokinin-like material in a model of anticipation of social defeat in the rat. J Neurosci 21:262-269. Medline

Becker C, Zeau B, Rivat C, Blugeot A, Hamon M, Benoliel JJ (2008) Repeated social defeat-induced depression-like behavioral and biological alterations in rats: involvement of cholecystokinin. Mol Psychiatry 13: 1079-1092. CrossRef Medline

Belcheva I, Belcheva S, Petkov VV, Petkov VD (1994) Asymmetry in behavioral responses to cholecystokinin microinjected into rat nucleus accumbens and amygdala. Neuropharmacology 33:995-1002. CrossRef Medline

Benoliel JJ, Bourgoin S, Mauborgne A, Pohl M, Legrand JC, Hamon M, Cesselin F (1992) GABA, acting at both GABAA and GABAB receptors, inhibits the release of cholecystokinin-like material from the rat spinal cord in vitro. Brain Res 590:255-262. CrossRef Medline

Berton O, McClung CA, Dileone RJ, Krishnan V, Renthal W, Russo SJ, Graham D, Tsankova NM, Bolanos CA, Rios M, Monteggia LM, Self DW, Nestler EJ (2006) Essential role of BDNF in the mesolimbic dopamine pathway in social defeat stress. Science 311:864-868. CrossRef Medline

Berton O, Covington HE 3rd, Ebner K, Tsankova NM, Carle TL, Ulery P, Bhonsle A, Barrot M, Krishnan V, Singewald GM, Singewald N, Birnbaum S, Neve RL, Nestler EJ (2007) Induction of $\delta$ FosB in the periaqueductal gray by stress promotes active coping responses. Neuron 55: 289-300. CrossRef Medline

Bewernick BH, Hurlemann R, Matusch A, Kayser S, Grubert C, Hadrysiewicz B, Axmacher N, Lemke M, Cooper-Mahkorn D, Cohen MX, Brockmann H, Lenartz D, Sturm V, Schlaepfer TE (2010) Nucleus accumbens deep brain stimulation decreases ratings of depression and anxiety in treatment-resistant depression. Biol Psychiatry 67:110-116. CrossRef Medline

Bradwejn J, Koszycki D, Shriqui C (1991) Enhanced sensitivity to cholecystokinin tetrapeptide in panic disorder: clinical and behavioral findings. Arch Gen Psychiatry 48:603-610. CrossRef Medline
Bremner JD (1999) Does stress damage the brain? Biol Psychiatry 45:797805. CrossRef Medline

Bremner JD (2006) Traumatic stress: effects on the brain. Dialogues Clin Neurosci 8:445-461. Medline

Bremner JD (2007) Neuroimaging in posttraumatic stress disorder and other stress-related disorders. Neuroimaging Clin North Am 17:523-538. CrossRef Medline

Britt JP, Benaliouad F, McDevitt RA, Stuber GD, Wise RA, Bonci A (2012) Synaptic and behavioral profile of multiple glutamatergic inputs to the nucleus accumbens. Neuron 76:790-803. CrossRef Medline

Burgos-Robles A, Bravo-Rivera H, Quirk GJ (2013) Prelimbic and infralimbic neurons signal distinct aspects of appetitive instrumental behavior. PLoS One 8:e57575. CrossRef Medline

Chen Q, Nakajima A, Meacham C, Tang YP (2006) Elevated cholecystokininergic tone constitutes an important molecular/neuronal mechanism for the expression of anxiety in the mouse. Proc Natl Acad Sci U S A 103:3881-3886. CrossRef Medline

Choi DC, Gourley SL, Ressler KJ (2012) Prelimbic BDNF and TrkB signaling regulates consolidation of both appetitive and aversive emotional learning. Transl Psychiatry 2:e205. CrossRef Medline

Christoffel DJ, Golden SA, Dumitriu D, Robison AJ, Janssen WG, Ahn HF, Krishnan V, Reyes CM, Han MH, Ables JL, Eisch AJ, Dietz DM, Ferguson D, Neve RL, Greengard P, Kim Y, Morrison JH, Russo SJ (2011) I $\kappa$ B kinase regulates social defeat stress-induced synaptic and behavioral plasticity. J Neurosci 31:314-321. CrossRef Medline

Covington HE 3rd, Kikusui T, Goodhue J, Nikulina EM, Hammer RP Jr, Miczek KA (2005) Brief social defeat stress: long lasting effects on cocaine taking during a binge and zif268 mRNA expression in the amygdala and prefrontal cortex. Neuropsychopharmacology 30:310-321. CrossRef Medline

Covington HE 3rd, Lobo MK, Maze I, Vialou V, Hyman JM, Zaman S, LaPlant Q, Mouzon E, Ghose S, Tamminga CA, Neve RL, Deisseroth K, Nestler EJ (2010) Antidepressant effect of optogenetic stimulation of the medial prefrontal cortex. J Neurosci 30:16082-16090. CrossRef Medline

Covington HE 3rd, Maze I, Sun H, Bomze HM, DeMaio KD, Wu EY, Dietz DM, Lobo MK, Ghose S, Mouzon E, Neve RL, Tamminga CA, Nestler EJ (2011) A role for repressive histone methylation in cocaine-induced vulnerability to stress. Neuron 71:656-670. CrossRef Medline

de Montigny C (1989) Cholecystokinin tetrapeptide induces panic-like attacks in healthy volunteers: preliminary findings. Arch Gen Psychiatry 46:511-517. CrossRef Medline

De Witte P, Heidbreder C, Roques B, Vanderhaeghen JJ (1987) Opposite effects of cholecystokinin octapeptide (CCK-8) and tetrapeptide (CCK-4) after injection into the caudal part of the nucleus accumbens or into its rostral part and the cerebral ventricles. Neurochem Int 10:473-479. CrossRef Medline

Diorio D, Viau V, Meaney MJ (1993) The role of the medial prefrontal cortex (cingulate gyrus) in the regulation of hypothalamic-pituitaryadrenal responses to stress. J Neurosci 13:3839-3847. Medline

Drevets WC (2001) Neuroimaging and neuropathological studies of depression: implications for the cognitive-emotional features of mood disorders. Curr Opin Neurobiol 11:240-249. CrossRef Medline

Fales CL, Barch DM, Rundle MM, Mintun MA, Snyder AZ, Cohen JD, Mathews J, Sheline YI (2008) Altered emotional interference processing in affective and cognitive-control brain circuitry in major depression. Biol Psychiatry 63:377-384. CrossRef Medline

Fales CL, Barch DM, Rundle MM, Mintun MA, Mathews J, Snyder AZ, Sheline YI (2009) Antidepressant treatment normalizes hypoactivity in dorsolateral prefrontal cortex during emotional interference processing in major depression. J Affect Disord 112:206-211. CrossRef Medline

Feder A, Nestler EJ, Charney DS (2009) Psychobiology and molecular genetics of resilience. Nat Rev Neurosci 10:446-457. CrossRef Medline

Gallopin T, Geoffroy H, Rossier J, Lambolez B (2006) Cortical sources of $\mathrm{CRF}, \mathrm{NKB}$, and CCK and their effects on pyramidal cells in the neocortex. Cereb Cortex 16:1440-1452. CrossRef Medline

Grubert C, Hurlemann R, Bewernick BH, Kayser S, Hadrysiewicz B, Axmacher N, Sturm V, Schlaepfer TE (2011) Neuropsychological safety of nucleus accumbens deep brain stimulation for major depression: effects of 12-month stimulation. World J Biol Psychiatry 12:516-527. CrossRef Medline

Grueter BA, Robison AJ, Neve RL, Nestler EJ, Malenka RC (2013) $\Delta$ FosB differentially modulates nucleus accumbens direct and indirect pathway function. Proc Natl Acad Sci U S A 110:1923-1928. CrossRef Medline 
Gygi SP, Rochon Y, Franza BR, Aebersold R (1999) Correlation between protein and mRNA abundance in yeast. Mol Cell Biol 19:1720-1730. Medline

Heidbreder CA, Groenewegen HJ (2003) The medial prefrontal cortex in the rat: evidence for a dorso-ventral distinction based upon functional and anatomical characteristics. Neurosci Biobehav Rev 27:555-579. CrossRef Medline

Holson RR (1986) Mesial prefrontal cortical lesions and timidity in rats: I. Reactivity to aversive stimuli. Physiol Behav 37:221-230. CrossRef Medline

Keedwell PA, Andrew C, Williams SC, Brammer MJ, Phillips ML (2005) The neural correlates of anhedonia in major depressive disorder. Biol Psychiatry 58:843-853. CrossRef Medline

Kennedy SH, Giacobbe P (2007) Treatment resistant depression: advances in somatic therapies. Ann Clin Psychiatry 19:279-287. CrossRef Medline

Kennedy SH, Evans KR, Krüger S, Mayberg HS, Meyer JH, McCann S, Arifuzzman AI, Houle S, Vaccarino FJ (2001) Changes in regional brain glucose metabolism measured with positron emission tomography after paroxetine treatment of major depression. Am J Psychiatry 158:899-905. CrossRef Medline

Krishnan V, Han MH, Graham DL, Berton O, Renthal W, Russo SJ, Laplant Q, Graham A, Lutter M, Lagace DC, Ghose S, Reister R, Tannous P, Green TA, Neve RL, Chakravarty S, Kumar A, Eisch AJ, Self DW, Lee FS, et al. (2007) Molecular adaptations underlying susceptibility and resistance to social defeat in brain reward regions. Cell 131:391-404. CrossRef Medline

Krishnan V, Nestler EJ (2008) The molecular neurobiology of depression. Nature 455:894-902. CrossRef Medline

Lehmann ML, Herkenham M (2011) Environmental enrichment confers stress resiliency to social defeat through an infralimbic cortex-dependent neuroanatomical pathway. J Neurosci 31:6159-6173. CrossRef Medline

Leistedt SJ, Linkowski P (2013) Brain, networks, depression, and more. Eur Neuropsychopharmacol 23:55-62. CrossRef Medline

Mayberg HS, Lozano AM, Voon V, McNeely HE, Seminowicz D, Hamani C, Schwalb JM, Kennedy SH (2005) Deep brain stimulation for treatmentresistant depression. Neuron 45:651-660. CrossRef Medline

Maze I, Covington HE 3rd, Dietz DM, LaPlant Q, Renthal W, Russo SJ, Mechanic M, Mouzon E, Neve RL, Haggarty SJ, Ren Y, Sampath SC, Hurd YL, Greengard P, Tarakhovsky A, Schaefer A, Nestler EJ (2010) Essential role of the histone methyltransferase G9a in cocaine-induced plasticity. Science 327:213-216. CrossRef Medline

McClung CA, Nestler EJ (2003) Regulation of gene expression and cocaine reward by CREB and DeltaFosB. Nat Neurosci 6:1208-1215. CrossRef Medline

Milad MR, Quirk GJ (2002) Neurons in medial prefrontal cortex signal memory for fear extinction. Nature 420:70-74. CrossRef Medline

Nahas Z, Anderson BS, Borckardt J, Arana AB, George MS, Reeves ST, Takacs I (2010) Bilateral epidural prefrontal cortical stimulation for treatmentresistant depression. Biol Psychiatry 67:101-109. CrossRef Medline

Nikulina EM, Arrillaga-Romany I, Miczek KA, Hammer RP Jr (2008) Long-lasting alteration in mesocorticolimbic structures after repeated social defeat stress in rats: time course of mu-opioid receptor mRNA and FosB/DeltaFosB immunoreactivity. Eur J Neurosci 27:2272-2284. CrossRef Medline

Noble F, Roques BP (1999) CCK-B receptor: chemistry, molecular biology, biochemistry and pharmacology. Prog Neurobiol 58:349-379. CrossRef Medline

Noble F, Wank SA, Crawley JN, Bradwejn J, Seroogy KB, Hamon M, Roques BP (1999) International Union of Pharmacology: XXI. Structure, distribution, and functions of cholecystokinin receptors. Pharmacol Rev 51:745-781. Medline

Pérez de la Mora M, Hernandez-Gómez AM, Méndez-Franco J, Fuxe K (1993) Cholecystokinin-8 increases $\mathrm{K}(+)$-evoked $\left[{ }^{3} \mathrm{H}\right]$ gammaaminobutyric acid release in slices from various brain areas. Eur J Pharmacol 250:423-430. CrossRef Medline

Perrotti LI, Hadeishi Y, Ulery PG, Barrot M, Monteggia L, Duman RS, Nestler EJ (2004) Induction of $\delta$ FosB in reward-related brain structures after chronic stress. J Neurosci 24:10594-10602. CrossRef Medline

Perrotti LI, Weaver RR, Robison B, Renthal W, Maze I, Yazdani S, Elmore RG, Knapp DJ, Selley DE, Martin BR, Sim-Selley L, Bachtell RK, Self DW, Nestler EJ (2008) Distinct patterns of DeltaFosB induction in brain by drugs of abuse. Synapse 62:358-369. CrossRef Medline

Radley JJ, Rocher AB, Miller M, Janssen WG, Liston C, Hof PR, McEwen BS, Morrison JH (2006) Repeated stress induces dendritic spine loss in the rat medial prefrontal cortex. Cereb Cortex 16:313-320. CrossRef Medline

Renthal W, Carle TL, Maze I, Covington HE 3rd, Truong HT, Alibhai I, Kumar A, Montgomery RL, Olson EN, Nestler EJ (2008) Delta FosB mediates epigenetic desensitization of the c-fos gene after chronic amphetamine exposure. J Neurosci 28:7344-7349. CrossRef Medline

Rezayat M, Roohbakhsh A, Zarrindast MR, Massoudi R, Djahanguiri B (2005) Cholecystokinin and GABA interaction in the dorsal hippocampus of rats in the elevated plus-maze test of anxiety. Physiol Behav 84:775782. CrossRef Medline

Richard JM, Berridge KC (2013) Prefrontal cortex modulates desire and dread generated by nucleus accumbens glutamate disruption. Biol Psychiatry 73:360-370. CrossRef Medline

Rotzinger S, Vaccarino FJ (2003) Cholecystokinin receptor subtypes: role in the modulation of anxiety-related and reward-related behaviours in animal models. J Psychiatry Neurosci 28:171-181. Medline

Schlaepfer TE, Cohen MX, Frick C, Kosel M, Brodesser D, Axmacher N, Joe AY, Kreft M, Lenartz D, Sturm V (2008) Deep brain stimulation to reward circuitry alleviates anhedonia in refractory major depression. Neuropsychopharmacology 33:368-377. CrossRef Medline

Sierra-Mercado D, Padilla-Coreano N, Quirk GJ (2011) Dissociable roles of prelimbic and infralimbic cortices, ventral hippocampus, and basolateral amygdala in the expression and extinction of conditioned fear. Neuropsychopharmacology 36:529-538. CrossRef Medline

Silva MG, Boyle MA, Finger S, Numan B, Bouzrara AA, Almli CR (1986) Behavioral effects of large and small lesions of the rat medial frontal cortex. Exp Brain Res 65:176-181. Medline

Somogyi P, Hodgson AJ, Smith AD, Nunzi MG, Gorio A, Wu JY (1984) Different populations of GABAergic neurons in the visual cortex and hippocampus of cat contain somatostatin- or cholecystokinin-immunoreactive material. J Neurosci 4:2590-2603. Medline

Surget A, Tanti A, Leonardo ED, Laugeray A, Rainer Q, Touma C, Palme R, Griebel G, Ibarguen-Vargas Y, Hen R, Belzung C (2011) Antidepressants recruit new neurons to improve stress response regulation. Mol Psychiatry 16:1177-1188. CrossRef Medline

Taniguchi H, He M, Wu P, Kim S, Paik R, Sugino K, Kvitsiani D, Fu Y, Lu J, Lin Y, Miyoshi G, Shima Y, Fishell G, Nelson SB, Huang ZJ (2011) A resource of Cre driver lines for genetic targeting of GABAergic neurons in cerebral cortex. Neuron 71:995-1013. CrossRef Medline

Teyssier JR, Ragot S, Chauvet-Gélinier JC, Trojak B, Bonin B (2011) Activation of a DeltaFOSB dependent gene expression pattern in the dorsolateral prefrontal cortex of patients with major depressive disorder. J Affect Disord 133:174-178. CrossRef Medline

Tsankova NM, Berton O, Renthal W, Kumar A, Neve RL, Nestler EJ (2006) Sustained hippocampal chromatin regulation in a mouse model of depression and antidepressant action. Nat Neurosci 9:519-525. CrossRef Medline

Tye KM, Prakash R, Kim SY, Fenno LE, Grosenick L, Zarabi H, Thompson KR, Gradinaru V, Ramakrishnan C, Deisseroth K (2011) Amygdala circuitry mediating reversible and bidirectional control of anxiety. Nature 471:358-362. CrossRef Medline

Vialou V, Robison AJ, Laplant QC, Covington HE 3rd, Dietz DM, Ohnishi YN, Mouzon E, Rush AJ 3rd, Watts EL, Wallace DL, Iñiguez SD, Ohnishi YH, Steiner MA, Warren BL, Krishnan V, Bolaños CA, Neve RL, Ghose S, Berton O, Tamminga CA, et al. (2010) DeltaFosB in brain reward circuits mediates resilience to stress and antidepressant responses. Nat Neurosci 13:745-752. CrossRef Medline

Vogt BA, Finch DM, Olson CR (1992) Functional heterogeneity in cingulate cortex: the anterior executive and posterior evaluative regions. Cereb Cortex 2:435-443. CrossRef Medline

Wilkinson MB, Xiao G, Kumar A, LaPlant Q, Renthal W, Sikder D, Kodadek TJ, Nestler EJ (2009) Imipramine treatment and resiliency exhibit similar chromatin regulation in the mouse nucleus accumbens in depression models. J Neurosci 29:7820-7832. CrossRef Medline

Winstanley CA, LaPlant Q, Theobald DE, Green TA, Bachtell RK, Perrotti LI, DiLeone RJ, Russo SJ, Garth WJ, Self DW, Nestler EJ (2007) DeltaFosB induction in orbitofrontal cortex mediates tolerance to cocaine-induced cognitive dysfunction. J Neurosci 27:10497-10507. CrossRef Medline

Yaksh TL, Furui T, Kanawati IS, Go VL (1987) Release of cholecystokinin from rat cerebral cortex in vivo: role of GABA and glutamate receptor systems. Brain Res 406:207-214. CrossRef Medline

Zanoveli JM, Netto CF, Guimarães FS, Zangrossi H Jr (2004) Systemic and intra-dorsal periaqueductal gray injections of cholecystokinin sulfated octapeptide (CCK-8s) induce a panic-like response in rats submitted to the elevated T-maze. Peptides 25:1935-1941. CrossRef Medline 